\title{
Strongyloides stercoralis
}

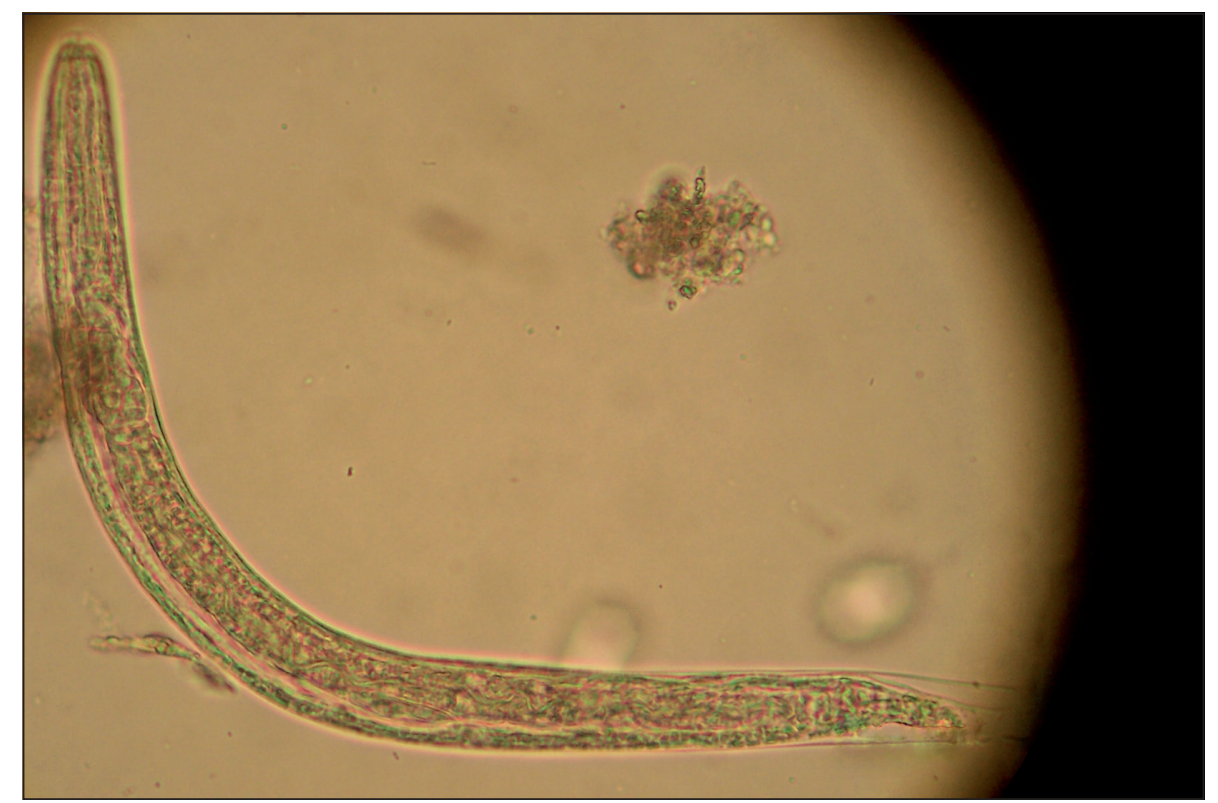

Figura 1. Larva rabditiforme de S. stercoralis. Montaje con lugol 40X (Foto de Lina Rivas, Universidad de Antioquia, Medellín, Colombia). La larva rabditiforme mide entre 200-300 $\mu \mathrm{m}$ de longitud por 16-20 $\mu \mathrm{m}$ de diámetro, se caracteriza por tener una cavidad bucal corta y un primordio genital prominente en la porción media. 


\section{Strongyloides stercoralis}

Strongyloides stercoralis es un parásito que forma parte del phylum nematoda, orden rhabditida, familia Strongyoloididae. Es endémico de regiones tropicales y subtropicales, siendo de baja prevalencia en climas templados. En Chile, se han descrito casos aislados y brotes en instituciones psiquiátricas. Se ha comunicado una seroprevalencia de $12,1 \%$ en pacientes psiquiátricos y de $0,25 \%$ en donantes de sangre. Morfológicamente se puede distinguir la forma parásita (hembra), las formas de vida libre (hembra y macho), la larva rabditiforme (Figura 1), la larva filariforme y los huevos.

La infección se adquiere cuando las larvas filariformes, presentes en la tierra u otro material contaminado con heces humanas, penetran la piel y migran vía hematógena hacia el pulmón, invadiendo los alvéolos. Desde ahí, ascienden por el árbol traqueobronquial y son deglutidas, alcanzando finalmente el intestino delgado, donde se transforman en su forma parásita adulta (hembra). Pueden vivir hasta cinco años en el intestino delgado, fundamentalmente en el duodeno y/o yeyuno, donde producen huevos, los cuales eclosionan y dan origen a las larvas rabditiformes (no infecciosas). Éstas se desarrollan y luego son eliminadas por las heces, continuando con el ciclo de vida libre. Generalmente la aparición de las larvas en las heces ocurre aproximadamente a la tercera o cuarta semana, desde el inicio de la infección. En ocasiones estas larvas pueden madurar dentro del tracto gastrointestinal, transformándose en larvas filariformes, las cuales penetran la piel perianal o la mucosa colónica, llegando a la circulación e iniciando un ciclo de autoinfección, el que aumenta substancialmente la carga intestinal de larvas.

Las manifestaciones clínicas de la infección son variadas. Puede presentarse desde eosinofilia asintomática o diarrea moderada en hospederos inmunocompetentes, hasta el síndrome de hiperinfección con shock séptico, en individuos con inmunocompromiso celular, con una alta mortalidad.

El diagnóstico confirmatorio de la infección no complicada requiere la visualización de larvas rabditiformes en las heces. No obstante, la eliminación es baja y temporalmente variable. Los métodos basados en la propiedad de hidrotropismo y termotropismo positivo de la larva, tales como Hoffmann, Baermann modificado y Rugai, tienen mejor sensibilidad. No obstante, el estándar de oro es el cultivo en placa de agar con la visualización posterior de trazos en el agar, correspondientes a larvas que arrastran bacterias. Por otra parte, la detección de IgG mediante ELISA, ha demostrado ser útil para el diagnóstico en personas inmunocompetentes y para estudios seroepidemiológicos.

\section{Referencias bibliográficas}

1.- Mercado R, Jercic M I, Ueta M. Infecciones por Strongyloides stercoralis en Chile. Bol Chil Parasitol 2001; 56: $72-5$.

2.- Mejia R, Nutman T. Screening, prevention, and treatment for hyperinfection syndrome and disseminated infections caused by Strongyloides stercoralis. Curr Opin Infect Dis 2012; 25: 458-63.

3.- Weller P, Leder K, Ryan E Baron E. Strongyloidiasis. New Orleans: Up To Date 2012. (acceso 30 de enero de 2013). Disponible en: http://www.uptodate.com/contents/strongyloidiasis.

Margareta Mühlhauser Hospital DIPRECA

$$
\text { Lina María Rivas }
$$
Alumna de Magíster en Microbiología Universidad de Chile 